\title{
ANALISIS DAN PENGEMBANGAN SITUS RESMI PARIWISATA INDONESIA DAN SISTEM INFORMASI PENDUKUNGNYA
}

\author{
Made Handijaya Dewantara \\ Email: made_handijaya_dewantara@yahoo.com
}

\begin{abstract}
There is a gap between the growth of internet utilization for tourism industry in Indonesia and unfortunate situation where showed from the rank of Indonesia in tourism and travel competitiveness index. In order to solve this problem, this research was conducted with three objectives as follows: to know the characteristics (strength and weakness) of current Indonesia tourism official website by a comparison with other official tourism website; to analyze the visitor's opinions about the current Indonesian tourism official website; and to develop the new content of Indonesia tourism official website including its information system. By using a qualitative descriptive analysis, it is found that the Indonesia official tourism website still has several weaknesses particularly on its content including languages variances, visa information, currency conversion, and direction or transportation, and also has several strengths particularly to display the diversity about Indonesia, through excellent photo gallery.
\end{abstract}

Keywords : official website, Indonesian tourism, information, system

\section{Pendahuluan}

Seiring dengan pesatnya era digital di seluruh belahan dunia, maka kemajuan ekonomi di Indonesia mendapat dukungan dari suksesi sektor teknologi informasi. Hal ini sejalan dengan laporan Kementerian Komunikasi dan Informasi tahun 2014 dan data terakhir dari pertemuan World Economic Forum 2014 di Manila, yang menyebutkan bahwa saat ini, masyarakat Indonesia menggunakan internet lebih banyak daripada menggunakan media cetak tradisional. Data ASEAN Information and Communication Index tahun 2014 juga mencatat bahwa Indonesia tercatat sebagai pengguna terbesar keempat sosial media Facebook tahun 2012, pecandu twitter ketujuh terbesar di dunia, atau sekitar 21\% dari total penduduk di Indonesia dalam jejaring sosial. Tentunya hal ini bisa dioptimalkan oleh sektor ekonomi tak terkecuali sektor pariwisata.

Gayung bersambut, ternyata sesuai prediksi UNCTAD 2005, teknologi informasi dan industri pariwisata di era modern ini memang benar-benar 
dalam hubungan saling menguntungkan. Faktanya, wisatawan saat ini tidak dapat dipisahkan dari internet dan teknologi untuk melakukan transaksi untuk tujuan perjalanan mereka. Mereka tidak bisa menunggu informasi yang biasanya diberikan oleh biro jasa atau wisata ke organisasi lain lagi, seperti apa yang terjadi 10 tahun yang lalu. Sebagian besar dari mereka, khususnya anak muda, benar-benar malas untuk melihat dan membaca brosur atau media tradisional lain untuk mendapatkan informasi tentang destinasi mereka. Mereka cukup berselancar di dunia maya, baik untuk mencari informasi, hingga bertransaksi dan mengatur perjalanan mereka. Sebagian besar dari mereka biasanya mengenal sebuah destinasi wisata baru dari situs resmi pariwisata sebuah daerah. Hal itulah menjadi alasan kuat banyak negara meluncurkan situs resmi pariwisata mereka. Pertanyaannya kini, apakah potensi kemajuan teknologi informasi di Indonesia sudah dimaksimalkan oleh industri pariwisatanya?

Sayangnya, berdasarkan laporan World Travel and Tourism Competitiveness Index, posisi Indonesia hanya ada pada peringkat ke-70 dari 140 negara di tahun 2012, dengan salah satu indikator kunci pada sistem informasi digital, yang masih belum bisa bersaing dengan negara-negara lain. Belum siapnya sistem informasi digital Indonesia mendukung bisnis pariwisata mereka juga tampak dari banyaknya travel agent online ilegal yang berdiri dari tahun ke tahun, sehingga membuat persaingan usaha tidak sehat. Hal ini sangat ironis sebab sebenarnya $e$-tourism (pariwisata berbasis elektronik) dapat memberikan setidaknya dua manfaat, yaitu murah dan cepat (memotong jalur distribusi).

Observasi awal menunjukkan memang sistem informasi e-tourism di Indonesia masih kurang memuaskan. Salah satunya muncul dari tampilan bahasa yang ada dan minimnya informasi yang ditawarkan. Berdasarkan latar belakang tersebut, muncul tiga rumusan masalah yang harus dijawab dalam penelitian ini, antara lain: (1) bagaimana situs resmi pariwisata Indonesia jika dibandingkan dengan negara kompetitornya dan bagaimana hal ini merefleksikan keunggulan dan kelemahannya?; (2) bagaimana pendapat pengunjung tentang situs resmi pariwisata Indonesia saat ini?; dan (3) bagaimana upaya-upaya yang bisa dilakukan untuk mengembangkan situs resmi pariwisata termasuk sistem informasinya?

\section{Metodologi}

Penelitian ini berjenis penelitian kualitatif yang berarti rumusan masalah akan dijawab secara otomatis melalui berbagai teknik pengumpulan data, lalu data dipilah, dan dipilih untuk proses analisis lebih lanjut, dengan menitikberatkan pada penelitian non-angka. Penelitian ini dilakukan di dua negara, khususnya di Indonesia dan Perancis selama kurang lebih 11 bulan. Proses pra-penelitian (meliputi pra-observasi dan pra-wawancara) dilakukan di Indonesia. Penelitian utama dilakukan di Perancis dimulai 
dengan studi komparasi sistem serta infrastruktur informasi dan komunikasi antara Indonesia dan Perancis secara umum. Objek utama penelitian ini adalah situs resmi pariwisata Indonesia yaitu www.indonesia.travel dan sistem informasi penunjangnya. Adapun objek penelitian lainnya adalah situs resmi pariwisata dari sembilan negara Asia Tenggara dan empat situs resmi negara di Eropa, Amerika, Asia, dan Australia.

Penelitian ini menggunakan tiga teknik pengumpulan data, yaitu observasi, wawancara, dan kuesioner. Teknik pertama adalah teknik observasi dengan melakukan pengamatan pada pengembangan objek utama penelitian dan sekaligus melakukan perbandingan dengan objek penelitian lainnya. Proses observasi dilakukan menurut indikator yang muncul dari penelitian Li (2010) dan Karupiah, Premalatha dan Eswari Sangaralingam Jaya (2008) yang memberikan sepuluh indikator. Teknik wawancara merupakan teknik yang digunakan untuk mengumpulkan data tambahan sekaligus untuk melengkapi data dari teknik observasi, sekaligus mengkonfirmasi jawaban dari para responden.

Informan kunci sebanyak empat orang berasal dari Kementerian Pariwisata dan Ekonomi Kreatif Divisi Komunikasi Digital dan Pencitraan, serta 20 responden kuesioner yang dipilih secara acak. Teknik terakhir adalah kuesioner. Kuesioner dibagikan kepada 120 responden yang merupakan sampel penelitian dari 174 populasi penelitian yaitu rata-rata jumlah pengunjung ke situs resmi pariwisata ini. Indikator pertanyaan untuk kuesioner dan wawancara diperoleh dari penelitian Crowder (2013) yang merumuskan beberapa indikator untuk menilai kualitas sebuah situs resmi dari pengunjungnya.

Untuk memastikan validnya data, responden dipilih tidak hanya yang berasal dari para wisatawan yang telah mengunjungi Indonesia untuk tujuan rekreasi, tetapi juga beberapa mitra bisnis, yang bahkan belum pernah bahkan telah mengunjungi Indonesia. Secara matematis, berikut proses perhitungan jumlah sampel penelitian dari populasi yang ada.

$$
\begin{aligned}
& \mathrm{n}=\mathrm{N} /\left(1+\mathrm{Ne}^{\wedge} 2\right)(\mathrm{n}=\text { sampel, } \mathrm{N}=\text { populasi, } \mathrm{e}=\text { marjin kesalahan }(0.05) \\
& \mathrm{n}=174\left(1+174 \times 0.05^{\wedge} 2\right) \\
& \mathrm{n}=174 / 1.435=121.2544(120 \text { responden })
\end{aligned}
$$

Terdapat dua bentuk analisis yang digunakan dalam menjawab tiga rumusan masalah untuk memperoleh kesimpulan. Analisis yang pertama adalah analisis deskriptif kualitatif. Analisis ini dilakukan dengan mengungkap fakta, hasil di lapangan, dan perbandingannya dengan teori yang ada. Akan tetapi, data-data kuantitatif serta isu-isu spesifik tetap dibahas dalam proses analisis ini untuk memperkaya data yang sudah ada

Proses analisis kedua adalah analisis studi komparasi untuk mengetahui 
kekuatan dan kelemahan baik dari situs resmi pariwisata Indonesia maupun sistem informasinya. Data-data yang terkumpul selanjutnya dipilah menurut masalah yang diteliti, selanjutnya dilakukan proses analisis awal, dan akan dilanjutkan dengan analisis akhir. Beberapa hasil analisis dideskripsikan baik melalui bagan maupun tabel. Kesimpulan akhir analisis selanjutnya digunakan untuk menjawab ketiga rumusan masalah.

\section{Studi Komparasi Situs Resmi Pariwisata Indonesia}

Evaluasi pada situs internet, khususnya situs resmi sangat penting untuk membantu organisasi atau perusahaan, khususnya untuk melacak kinerja situs mereka dalam satu periode waktu. Evaluasi juga diperlukan untuk melakukan perbaikan terus-menerus serta mengukur kinerja situs mereka dengan kompetitor lainnya (Henderson, 2005). Evaluasi situs internet juga menjadi penting di saat pembuatan situs internet menjadi lebih mudah. Hal ini disebabkan karena munculnya situs ilegal dengan informasi yang sulit dipercaya bahkan mengandung iklan atau virus. Khusus untuk situs pariwisata resmi Indonesia, maka komparasi dilakukan dengan beberapa negara kompetitornya di Asia Tenggara dan empat negara berbeda yang berasal dari Amerika, Asia, Australia, dan Eropa. Hasil komparasi tersebut akan muncul dalam kedua tabel berikut ini.

Tabel 1 Komparasi Situs Resmi Pariwisata Indonesia dengan Negara ASEAN Lainnnya

\begin{tabular}{|c|c|c|c|c|c|c|c|c|c|c|}
\hline $\begin{array}{c}\text { Negara } \\
\text { Indikator }\end{array}$ & $\overleftrightarrow{\mathbf{z}}$ & $\sum_{i}^{\infty}$ & Z & $\mathbb{E}$ & $\stackrel{5}{5}$ & $\Xi$ & 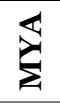 & 㝵 & $\mathscr{0}$ & $\sum_{U}$ \\
\hline Kalendar Acara & $\boldsymbol{0}$ & 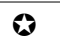 & $\boldsymbol{\theta}$ & $\boldsymbol{\theta}$ & is & 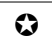 & $\star$ & $\star$ & is & is \\
\hline Berita Terbaru & से & - & is & is & is & $\star$ & $\star$ & b & ¿ & is \\
\hline Detail Visa & से & $\mathbf{0}$ & is & $\boldsymbol{\theta}$ & is & b & $\star$ & $\star$ & 8 & $\star$ \\
\hline Konversi Mata Uang & is & $\boldsymbol{0}$ & 0 & $\boldsymbol{D}$ & is & $\boldsymbol{D}$ & $\star$ & 0 & $\star$ & $\star$ \\
\hline Variasi Bahasa & is & $\boldsymbol{D}$ & $\boldsymbol{\theta}$ & $\boldsymbol{D}$ & $\star$ & is & $\star$ & is & is & $\star$ \\
\hline Informasi Tambahan & $\star$ & $\boldsymbol{D}$ & 0 & is & $\star$ & $\star$ & is & $\star$ & $\star$ & $\star$ \\
\hline Transportasi & $\star$ & $\boldsymbol{\theta}$ & $\boldsymbol{\theta}$ & is & $\star$ & $\boldsymbol{0}$ & $\star$ & $\star$ & 0 & $\boldsymbol{\theta}$ \\
\hline Galeri Foto & D & D & $\boldsymbol{\Delta}$ & 0 & $\boldsymbol{0}$ & is & से & $\star$ & $\star$ & $\boldsymbol{\Delta}$ \\
\hline Informasi Kontak & है & D & $\boldsymbol{\Delta}$ & 0 & $\star$ & is & से & $\star$ & औ & is \\
\hline Link Agen Perjalanan & है & D & $\boldsymbol{\Delta}$ & 0 & is & (- & 0 & और & $\star$ & $\star$ \\
\hline Informasi Cuaca & $\star$ & 0 & 0 & $\star$ & $\star$ & - & $\star$ & 0 & $\star$ & $\star$ \\
\hline
\end{tabular}

Indeks:

INA : Indonesia

SIN : Singapura

VIE : Vietnam

MYA : Myanmar

MAS : Malaysia

THA : Thailand

PHI : Filipina

BDS : Brunei Darussalam CAM : Kamboja

- Bagus (or top 5 in ASEAN)

is : Sedang-sedang (needs improvement)

$\star \quad$ : Buruk (no information)

Tabel 1 komparasi ini memberikan gambaran posisi Indonesia terhadap 
sembilan negara lainnya, bahwa situs resmi pariwisata Indonesia masih memiliki beragam kekurangan, khususnya di informasi transportasi dan cuaca. Indonesia juga bisa melihat pada situs resmi pariwisata Malaysia, Singapura, dan Thailand yang memiliki kualitas lebih baik, khususnya pada variasi bahasa dan link untuk agen perjalanan.

Tabel 2 Komparasi Situs Resmi Pariwisata Indonesia dengan Perancis, Amerika Serikat, Australia, dan Korea Selatan

\begin{tabular}{|c|c|c|c|c|c|}
\hline Negara Indikators & INA & FRA & USA & AUS & ROK \\
\hline Kalendar Acara & $\boldsymbol{\theta}$ & $\boldsymbol{\theta}$ & $\boldsymbol{D}$ & $\boldsymbol{\theta}$ & 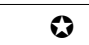 \\
\hline Berita Terbaru & और & $\boldsymbol{\Delta}$ & है & 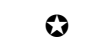 & 0 \\
\hline Detail Visa & औ & $\boldsymbol{\Delta}$ & (- & D & 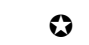 \\
\hline Konversi Mata Uang & और & औ & - & D & 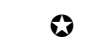 \\
\hline Variasi Bahasa & औ & $\boldsymbol{\Delta}$ & (- & D & 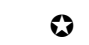 \\
\hline Informasi Tambahan & $\star$ & $\boldsymbol{\Delta}$ & - & D & 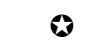 \\
\hline Transportasi & $\star$ & 0 & $\boldsymbol{\theta}$ & - & $\boldsymbol{\theta}$ \\
\hline Galeri Foto & $\boldsymbol{\theta}$ & - & $\boldsymbol{\theta}$ & - & 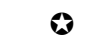 \\
\hline Informasi Kontak & is & is & $\star$ & - & से \\
\hline Link Agen Perjalanan & से & $\boldsymbol{\theta}$ & और & - & से \\
\hline Informasi Cuaca & $\star$ & 0 & $\star$ & 0 & $\varnothing$ \\
\hline
\end{tabular}

Index:

INA : Indonesia FRA : Perancis

USA : Amerika Serikat AUS : Australia

ROK : Korea Selatan

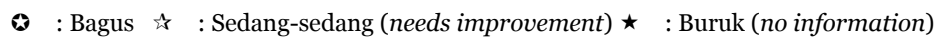

Tabel 2 jelas membuktikan bahwa kualitas situs resmi pariwisata Indonesia berada jauh di bawah keempat negara yang sudah memiliki infrastruktur teknologi informasi maju. Kedua tabel komparasi di atas menunjukkan perlunya Indonesia untuk belajar dari kompetitornya sendiri untuk mengembangkan situs resmi pariwisatanya. Kompetitor Indonesia dengan indeks informasi teknologi tersukses, Singapura, membangun sistem informasi pariwisata mereka melalui pembangunan infrastruktur teknologi informasi dengan sukses. Singapura menduduki peringkat ke-2o dengan skor 5,2. Brunei Darussalam adalah negara kedua dengan infrastruktur teknologi informasi tersukses di Asia Tenggara dengan skor 3,9 (peringkat ke-47), diikuti oleh Malaysia (peringkat ke-52). Kelompok ketiga terdiri dari Vietnam (67) dan Thailand (ke-81). Indonesia sendiri berdiri di bawah negara-negara tersebut yaitu di posisi ke-96 bersama dengan Filipina (98), serta Kamboja (123). Kualitas dan peringkat sistem informasi, komunikasi, dan teknologi di Indonesia ini memberikan sinyal buruk bagi perbaikan situs resmi pariwisata saat ini, termasuk sistem informasinya. Akan tetapi, pada saat yang sama, warga Indonesia melalui hobi berjejaring sosialnya 
dipandang sebagai pemain utama sekaligus pondasi yang kuat untuk implementasi internet di bisnis pariwisata.

Asia tenggara memang telah menjadi sebuah kawasan dengan peningkatan penggunaan internet khususnya sosial media yang cukup masif, tak terkecuali di Indonesia. Sayangnya, di Indonesia, potensi masifnya kenaikan penggunaan sosial media oleh masyarakatnya belum banyak dimanfaatkan oleh sektor industri pariwisata. Dalam data ASEAN Tourism Competitiveness Index, data menunjukkan bahwa serapan internet untuk tujuan bisnis pariwisata masih dikuasai oleh Singapura dengan $71 \%$ dan Malaysia (56\%), sementara Indonesia hanya $25 \%$.

Permasalahan klasik dalam proses komunikasi pemasaran pariwisata di Indonesia saat ini sebenarnya bisa diatasi dengan pembenahan situs resmi pariwisata. Sayangnya, berdasarkan hasil komparasi, situs resmi pariwisata Indonesia masih memiliki kekurangan seperti tidak adanya sistem informasi yang terintegrasi dari keseluruhan provinsinya, tidak adanya layanan informasi transportasi, dan kurangnya variasi bahasa. Akan tetapi, situs resmi pariwisata Indonesia juga memiliki keunggulan di bidang galeri foto yang ditampilkan, video, dan tampilan keberagaman budaya serta alam di Indonesia. Hasil observasi menyebutkan bahwa sistem pariwisata elektronik (e-tourism) di Indonesia masih terbatas pada penampilan informasi berbasis teks dan penyediaan gambar, tanpa komunikasi interaktif antar pengguna situs dan pengembang situs.

\section{Pendapat Pengunjung Situs Resmi Pariwisata Indonesia}

Kuesioner disebarkan kepada pengunjung situs melalui sistem elektronik pada beberapa responden yang berasal dari Amerika Serikat, Inggris, Prancis, Spanyol, Meksiko, Cina, Jerman, Belanda, Jepang, Korea Selatan, Tunisia, Mesir, India, Arab Saudi, Vietnam, Malaysia, Singapura, Hongaria, Rumania, Polandia, Afrika Selatan, Swiss, Slovakia, Indonesia, dan Filipina. Kuesioner dilakukan secara online melalui forum wisatawan yang pernah atau akan berkunjung ke Indonesia sebagai couchsurfing.org forum, media sosial (Facebook dan twitter), forum wisatawan Indonesia, backpacker dan forum online. Berdasarkan lokasi saat mengakses kuesioner ini, data mencatat 47.50\% di kawasan Asia Tenggara, 43.33\% responden berada di Eropa, masing-masing 2,5\% responden di kawasan Asia Timur dan Asia Selatan, 1,67\% Afrika dan Australia (Oceania), dan 0.83\% berada di Amerika. Hal ini memberikan gambaran bahwa pasar yang ideal dari industri bisnis pariwisata Indonesia akan berasal dari kawasan Asia Tenggara (Singapura, Malaysia, dan Filipina) dan Eropa (Inggris dan Perancis).

Dalam proses kuesioner tersebut, peneliti juga menanyakan kepada responden tentang frekuensi kedatangan ke Indonesia. Sebagian besar responden (47.50\%) yang berasal dari negara-negara di Asia Tenggara 
seperti Malaysia, Singapura, dan Filipina menyatakan mereka sering datang ke Indonesia. Salah seorang responden dari Singapura, Herman, mengatakan bahwa kemudahan dan harga transportasi udara dari negaranya ke Indonesia adalah alasan kuat datang ke Indonesia, baik dengan motif berwisata atau bisnis. Sayangnya, menurut Herman, kurangnya informasi tentang destinasi wisata lainnya mempersempit pilihan destinasi yang bisa dia raih ke Indonesia, baik untuk motif bisnis maupun bersenang-senang.

Responden juga ditanya mengenai seberapa sering mereka menggunakan website pariwisata resmi untuk berwisata. Sebagian besar responden menyatakan mereka sering mengunjungi situs resmi pariwisata sebelum berwisata (41,67\%). Ketika respon ini dikonfirmasi ke salah seorang responden bernama Tony, dia menyatakan alasannya selalu mengakses situs internet karena biasanya situs itu biasanya memberikan rincian informasi. Data kuesioner lainnya menunjukkan bahwa sebagian besar responden (33,33\%) telah menggunakan internet untuk berwisata selama lebih dari 6 tahun. Dua data kuesioner ini menunjukkan bahwa era sistem pariwisata tradisional sudah berakhir dan digantikan era pariwisata berbasis teknologi digital. Oleh karena itu, ada baiknya pemerintah mengubah fokus promosi mereka, dengan mengembangkan situs resmi pariwisata daripada melakukan penyebaran brosur.

Responden juga ditanya tentang betapa pentingnya kegunaan dan fungsi dari situs resmi pariwisata sebuah negara sebagai langkah pertama dalam persiapan mereka sebelum berwisata. Hasilnya, dalam kuesioner, dari jawaban yang diperoleh, sebagian besar responden (37,50\%) menyatakan bahwa situs pariwisata itu penting, dan 29.17\% menyatakan sangat penting.

Dalam sebuah wawancara dengan responden dari Vietnam, Nguyen, dia mengatakan bahwa untuk mendukung sistem informasi pariwisata, terutama di Asia Tenggara, tampilan keberagaman budaya maupun kekayaan alam wajib didukung oleh sebuah situs pariwisata resmi. Menurutnya terdapat beberapa alasan mengapa sebuah situs pariwisata resmi sebuah negara begitu penting dalam sebuah usaha promosi wisata, antara lain, karena sering munculnya situs-situs tidak resmi, tidak dapat dipercaya, dan penuh dengan berita sampah (spam). Selain itu, ketika disodorkan situs resmi pariwisata Indonesia, responden ini berpendapat dia dapat menemukan banyak hal yang dia tidak tahu sebelumnya tentang Indonesia.

Ketika ditanya mengenai tingkat kepercayaan mereka pada kehandalan dan keakuratan informasi situs resmi pariwisata Indonesia, mayoritas responden percaya dan setuju bahwa untuk mendapatkan informasi yang dapat dipercaya dan dihandalkan, mereka harus mengaksesnya melalui situs resmi pariwisata Indonesia. Sejumlah 50,83\% responden menyatakan setuju dan 24,17\% responden menyatakan sangat setuju. Ketika hal ini dikonfirmasi ke salah satu responden dari Korea Selatan, responden tersebut 
beralasan bahwa situs resmi yang berasal dari pemerintah secara umum memiliki informasi yang akurat, dan dapat dipertanggungjawabkan. Selain itu, tingkat keamanan dari situs resmi ini lebih tinggi dibandingkan situs pariwisata lainnya. Menurut responden, keuntungan lainnya akan dirasakan para akademisi dan peneliti yang dapat melakukan studi tentang kekayaan tujuan wisata di Indonesia secara mudah melalui situs resmi pariwisata Indonesia.

Meskipun mayoritas responden memberikan respon dan pendapat positif mereka pada situs resmi pariwisata Indonesia, ternyata sebagian besar dari mereka justru mengharapkan perbaikan dan peningkatan kualitas situs ini. Berdasarkan hasil kuesioner, sebanyak $45 \%$ responden menyatakan setuju dan 31,67\% responden menyataakan sangat setuju pada peningkatan kualitas situs ini.

Ketika dikonfirmasi ke salah satu responden dari India, responden itu berpendapat bahwa informasi setiap kota di Indonesia yang ada saat ini dan penambahan fasilitas chat room perlu dilakukan dan ditingkatkan. Seorang responden Jepang juga mengatakan bahwa meskipun secara keseluruhan dia menyukai tampilan situs ini, dia berharap kualitas bahasa Jepang yang ada dalam situs dapat ditingkatkan. Kedua tanggapan tersebut adalah bukti bahwa mereka memberikan kritik sebagai bukti loyalitas mereka dalam menggunakan situs yang terpercaya serta resmi. Dalam rating, responden memberikan penilaian cukup bagus (tiga bintang) untuk rating situs ini, yaitu sejumlah $39.17 \%$ responden.

\section{Pengembangan Situs Resmi Pariwisata Indonesia dan Sistem Informasinya}

Pengembangan situs resmi pariwisata Indonesia, yang berfokus pada pengembangan konten dapat dimulai dari perbaikan halaman depan (homepage), lalu diikuti konten about Indonesia (hal-hal mengenai Indonesia), konten discover Indonesia (menjelajahi Indonesia), dan konten merencanakan liburan ke Indonesia. Bagian utama dari perbaikan homepage ini ada pada penambahan variasi bahasa, visa, galeri foto, galeri video, konversi mata uang, dan kemudahan akses ke sosial media. Halaman depan situs harus dibuat sesederhana mungkin, dengan tampilan secepat mungkin, dan navigasi semudah mungkin. Situs juga hendaklah dibuat seefisien mungkin untuk memberikan kesan pertama yang menarik bagi pengunjung untuk menjelajahi situs lebih lanjut. Halaman depan juga harus memberikan gambaran menyeluruh mengenai seluruh isi situs, dengan penyampaian benchmark (Wonderful Indonesia) sesering mungkin.

Pada halaman depan ini nantinya akan memuat beberapa sub-bagian dari masing-masing sub-folder, seperti konten "About Indonesia", "Discover Indonesia" dan "Plan to Indonesia". Penambahan peta kecil dengan 
33 kota besar di masing-masing provinsi di Indonesia dapat diberikan agar pengunjung mendapat gambaran umum mengenai Indonesia. Pengintegrasian video dari situs YouTube atau Vimeo juga bisa dilakukan dan diperbarui setiap hari yang memuat promosi seluruh destinasi wisata di Indonesia.

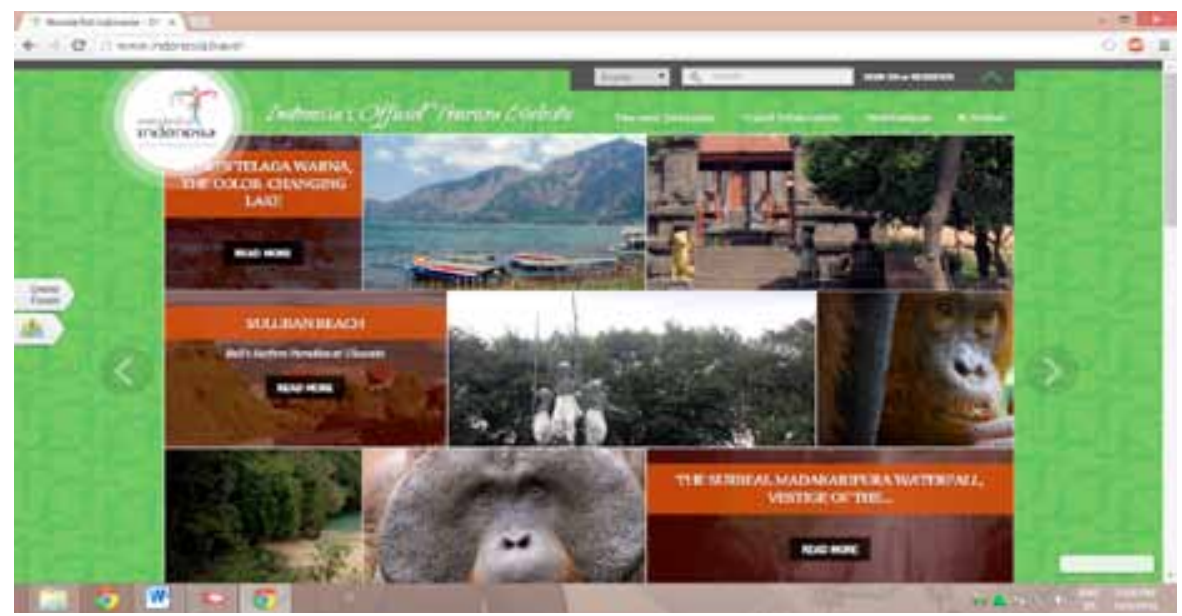

Foto 1 Homepage Situs Resmi Pariwisata Indonesia

Bagian selanjutnya adalah konten mengenai hal-hal tentang Indonesia dan mendeskripsikan apa saja yang ada di Indonesia melalui About and Discover Indonesia yang memuat beragam konten seperti travel stories, news, events, frequently asked question, travel information, destinations, dan activities. Konten ini lebih bersifat deskriptif dan informatif dengan menampilkan seluruh kekayaan potensi wisata di seluruh destinasi wisata di Indonesia. Konten yang cukup penting disampaikan dengan pembaruan secara berkala adalah konten mengenai budaya dan kekayaan alam Indonesia, yang menjadi alasan utama turis datang ke nusantara. Dalam informasi konten tersebut, nantinya akan memuat sebuah peta cukup besar dengan link tautan berupa galeri foto pada masing-masing provinsi di Indonesia. Konten ini akan memberikan gambaran jelas mengenai keberagaman Indonesia.

Pada konten ini, juga akan dimuat hal-hal yang bisa dilakukan di Indonesia, sekaligus acara-acara yang akan digelar. Kecepatan navigasi dan kemudahan akses menuntut agar tampilan situs dibuat seringkas mungkin tanpa mengurangi esensi Indonesia yang berbasis keberagaman. Hal yang tidak kalah pentingnya untuk ditampilkan adalah mengenai sejarah Indonesia, bahasa Indonesia, kondisi cuaca, serta waktu di Indonesia. 


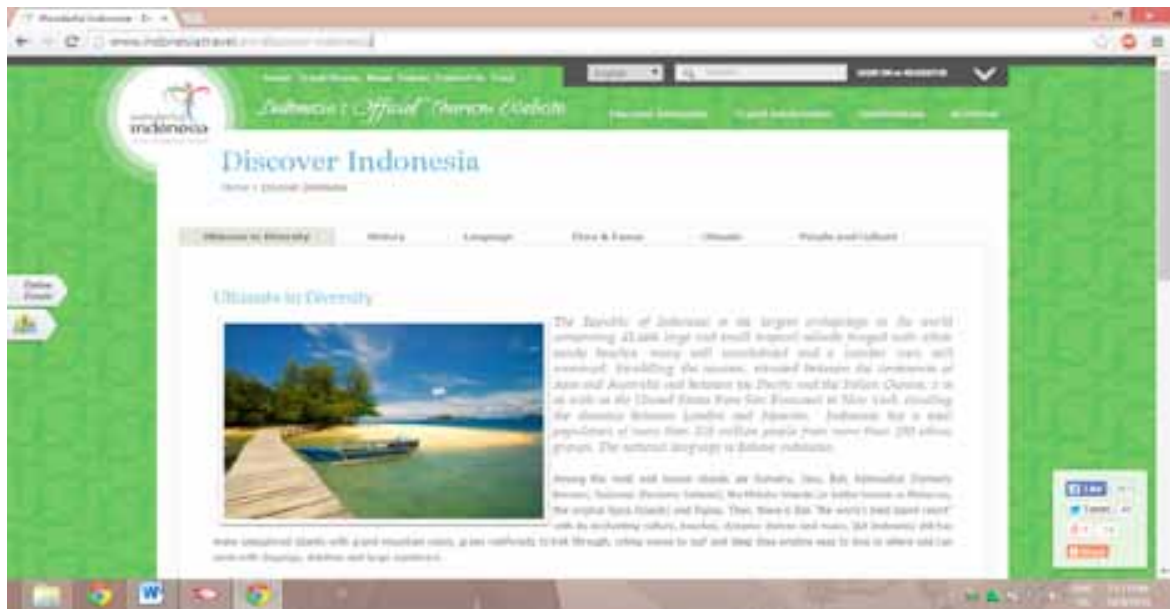

Foto 2 Konten About and Discover Indonesia

Setelah menelaah mengenai konten About Indonesia dan pengunjung situs mengerti apa saja yang bisa dilakukan di Indonesia melalui konten Explore Indonesia, maka pengunjung situs akan bisa diarahkan pada proses perencanaan perjalanan mereka ke Indonesia. Konten yang bisa digunakan di sini adalah Plan to Indonesia... Let's Make it Happen. Dalam konten ini, pengembang situs tentu saja memerlukan kerjasama dengan pihak ketiga baik dengan perusahaan channel manager, GDS (global distribution system), dan perusahaan penyedia layanan pariwisata lainnya. Konten ini nantinya akan membantu wisatawan untuk merencanakan di mana mereka tinggal, bagaimana mereka dapat berpindah tempat dari satu destinasi ke destinasi lain, hingga tips-tips dalam berwisata di Indonesia.

Untuk mencegah persaingan dengan online travel agent (OTA), maka situs resmi pariwisata Indonesia dapat bekerja sama dengan produk-produk penyedia jasa wisata nasional seperti perusahaan INNA Hotels, maskapai BUMN, PT KAI, dan penyedia jasa pelayaran nasional. Dengan kata lain, konten ini lebih sebagai alat promosi perusahaan nasional yang terlibat dalam industri pariwisata nasional.

Jenis pariwisata yang cukup baru namun sudah cukup sering diadakan di Indonesia adalah jenis pariwisata MICE (meeting, conference, incentive, and exhibition). Berdasarkan data dari Masruroh (2012) dalam data MICE yang diluncurkan oleh Kementerian Kebudayaan dan Pariwisata, terjadi kenaikan jumlah wisatawa MICE dari tahun ke tahun. Sejak tahun 2005 hingga tahun 2012, selalu terjadi kenaikan rasio wisatawan MICE terhadap jumlah wisatawan asing yang datang ke Indonesia. Contohnya, di tahun 2005, hanya terdapat 67.147 wisatawan dari 5.002.101 wisatawan asing ke Indonesia atau 1.34\% kontribusi. Akan tetapi, di tahun 2010, jumlah persentase kontribusi ini meningkat hingga empat kali lipat. Pesatnya pertumbuhan pariwisata 


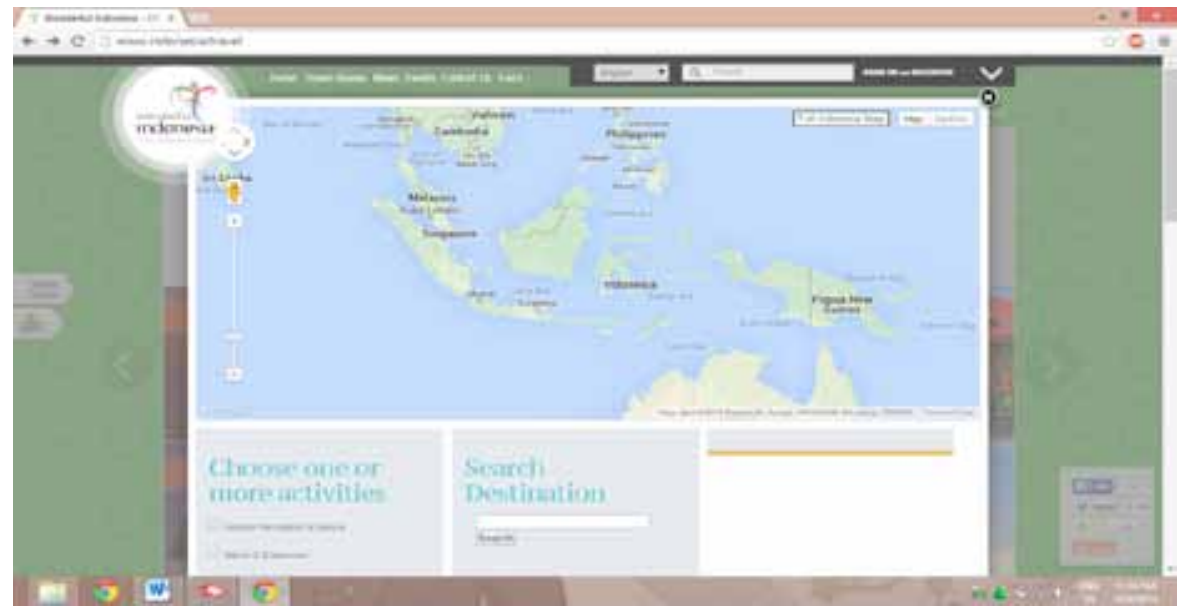

Foto 3 Konten Plan to Indonesia

MICE tentunya harus memperoleh perhatian dari kementerian pariwisata termasuk untuk menampilkannya dalam situs resmi pariwisata Indonesia.

Hal lainnya yang cukup penting untuk ditambahkan di situs ini adalah fasilitias forum. Pada fasilitas forum ini ada baiknya diberikan fasilitas chat, yang digunakan untuk mempermudah interaksi antara user dan developer. Kemudahan komunikasi akan mempermudah pengembang situs untuk memperoleh masukan dan informasi terbaru dari pengunjung situs. Adanya forum juga akan mempercepat pemerintah dan perusahaan pariwisata dalam merancang destinasi wisata sesuai kebutuhan dan keinginan calon wisatawan. Untuk mengembangkan situs resmi yang berkualitas, terdapat beberapa karakteristik yang bisa diikuti seperti, kejelasan informasi, kemudahan navigasi, kecepatan, interaktivitas, dan aksesibilitas.

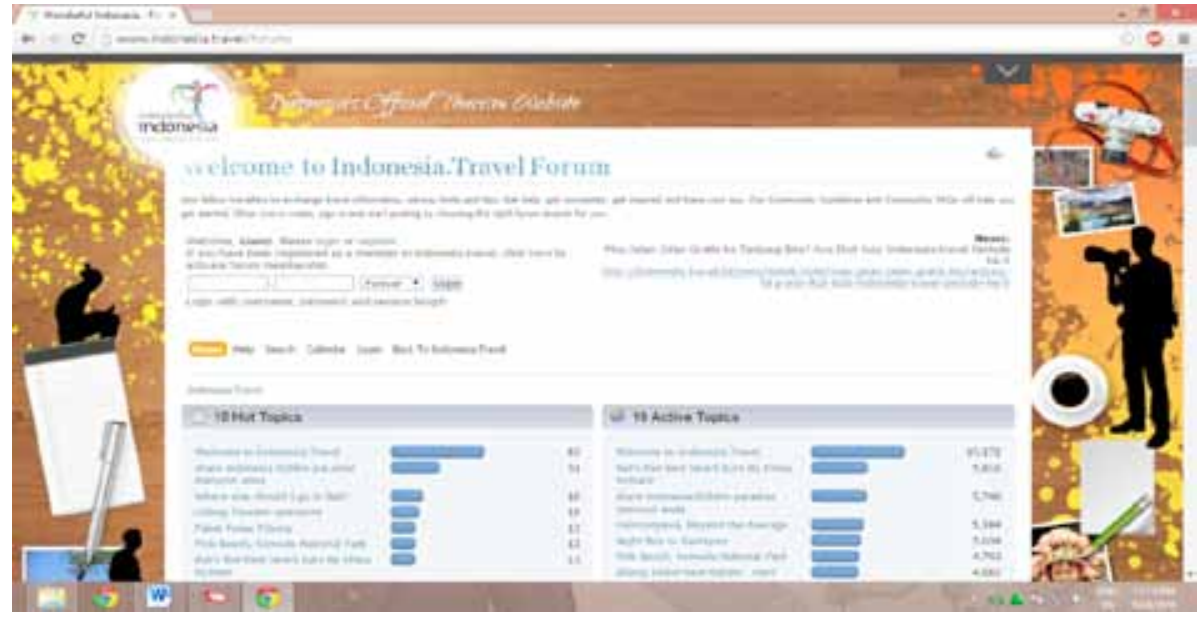

Foto 4 Konten Forum 
Sistem informasi yang terintegrasi tentunya akan membantu pengembang situs dalam menyediakan informasi yang lengkap dan terbarukan. Nantinya, situs tidak hanya dikembangkan oleh para pengembang situs, melainkan juga oleh para pengunjung situs, termasuk masyarakat Indonesia yang memiliki hobi bersosial media. Para pengguna situs nantinya bisa mengirimkan informasi dalam format bahasa WSP (wireless session protocol) ataupun WTP (wireless transaction protocol) dalam memberikan informasi mereka ke pihak pengembang situs. Bahkan, apabila nantinya fasilitas sosial media menyediakan layanan ini, maka pengguna situs dapat dengan mudah memberikan foto ataupun video mereka ke situs resmi ini. Hal ini selain akan berguna untuk memperkaya informasi dalam situs resmi ini, juga dapat meningkatkan posisi situs pada search engine apabila seorang calon wisatawan ingin mencari informasi tentang pariwisata Indonesia.

Tidak hanya melalui bahasa WSP ataupun WTP, pengunjung situs juga bisa memberikan data mereka secara sederhana melalui kantor dinas pariwisata di kota tersebut, dan selanjutnya dikirimkan hingga kantor pengembang situs di Jakarta melalui bahasa HTTP. Untuk merangsang minat para pengunjung situs, pengembang situs dapat menyelenggarakan kompetisi blog, kompetisi fotografi, atau bahkan kompetisi pemerkaya konten. Untuk menjelaskan sistem informasi terintegrasi pariwisata Indonesia di masa depan, dapat dilihat melalui bagan berikut ini.

\section{Bagan Sistem Informasi Situs Resmi Pariwisata Indonesia di Masa Depan}

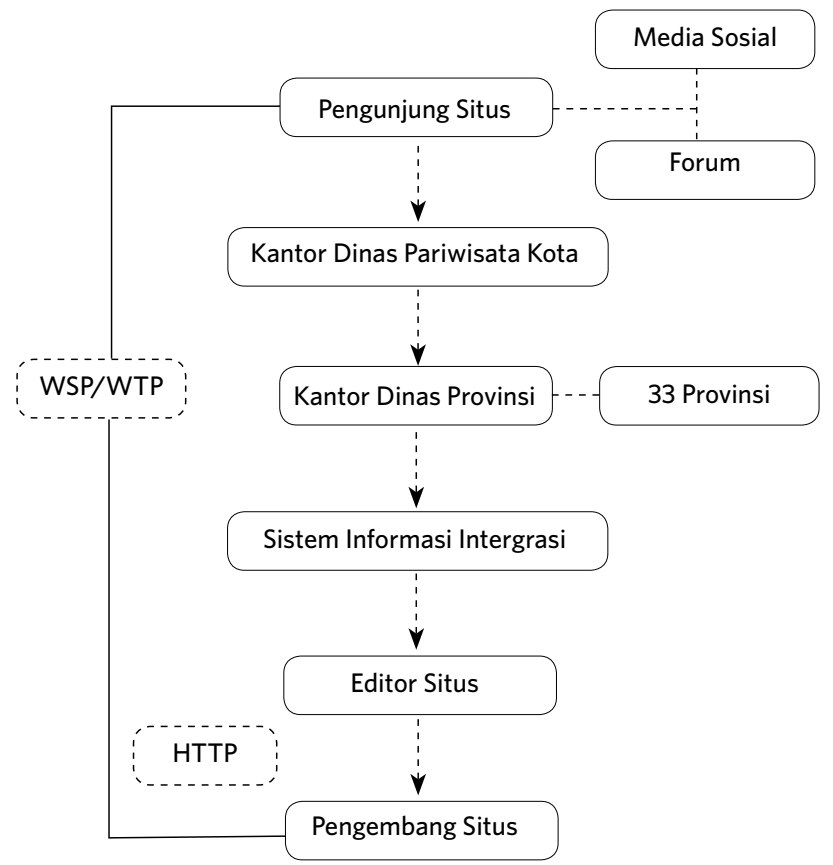




\section{Kesimpulan dan Saran}

Berdasarkan uraian yang telah dijelaskan dapat disimpulkan tiga poin antara lain. Pertama, situs resmi pariwisata Indonesia masih memiliki beberapa kelemahan terutama pada konten di dalamnya seperti variasi bahasa, informasi visa, konversi mata uang, dan transportasi. Namun, situs ini juga memiliki beberapa keunggulan yang menunjukkan karakter keberagaman Indonesia melalui galeri foto dan video.

Kedua, pendapat pengunjung tentang situs resmi pariwisata Indonesia saat ini ditunjukkan dari hasil kuesioner yaitu ketika mayoritas responden (39.17\%) memberikan tiga bintang atau menyatakan kualitas situs resmi ini cukup bagus, namun tetap memerlukan peningkatan kualitas dan kecepatan. Para responden dan informan percaya bahwa situs resmi dan sistem informasi yang terintegrasi akan memberikan manfaat, tidak hanya untuk diri mereka sendiri tetapi juga untuk pihak pemerintah. Oleh karena itu, situs resmi ini perlu diperbaharui secara berkala, diaudit, dan dikembangkan. Para wisatawan dan calon mitra bisnis ingin adanya pengembangan konten pada tampilan peta serta sistem informasi transportasi.

Ketiga, dalam kaitannya dengan pengembangan situs resmi, pengembang situs harus mengembangkan konten khususnya pada halaman depan (bahasa, peta, integrasi media sosial, video, dan update berita); About Indonesia dan Discover Indonesia, kota di Indonesia, dan bagaimana melakukan perencanaan perjalanan ke Indonesia. Untuk mengembangkan situs resmi yang berkualitas, terdapat beberapa karakteristik yang bisa diikuti seperti, kejelasan informasi, kemudahan navigasi, kecepatan, interaktivitas, dan aksesibilitas.

Mekanisme sistem informasi akan banyak dijalankan oleh pengguna situs (baik turis maupun mitra bisnis). Mereka diharapkan dapat mengirimkan data mereka baik melalui bahasa WSP atau WTP secara langsung ke sistem informasi pusat di Jakarta. Atau, di sisi lain, mereka dapat berbagi pengalaman mereka ketika mereka melakukan perjalanan pada destinasi di Indonesia, melalui dinas pariwisata di setiap kota di Indonesia, dan kemudian dikirimkan ke dinas provinsi, diedit melalui redaktur situs resmi, dan berakhir pada pengembang situs, melalui bahasa HTTP.

Studi ini juga ingin memberikan beberapa saran kepada pihak-pihak terkait seperti kepada pemerintah Republik Indonesia, dalam hal ini Kementerian Pariwisata, untuk melakukan analisis berkala demi peningkatan kualitas situs resmi pariwisata Indonesia, sesuai dengan apa yang yang diinginkan oleh para pengguna.

Saran kedua disampaikan ke dinas pariwisata di 33 provinsi di Indonesia, untuk melakukan perbaikan dan pengembangan lokasi wisata mereka, dan sekaligus mencatatnya dalam format digital untuk diintegrasikan dalam sebuah situs resmi. Konten tersedia di situs pariwisata resmi di 33 provinsi ini 
nantinya harus selaras dengan apa yang muncul di situs pusat. Lebih lanjut, ada baiknya agar dinas pariwisata dapat mengintegrasikan situs ini pada fasilitas media sosial serta penambahan fasilitas chat room. Pemerintah juga sebaiknya bekerja sama dengan perusahaan pengembang situs profesional dan berpengalaman. Saran juga diberikan kepada wisatawan yang akan berperan dalam pemerkaya konten situs ini.

Saran ketiga ditujukan kepada wisatawan Indonesia yang memiliki kebiasaan bersosial media, untuk membantu memperkaya data, foto, video, dan informasi di situs resmi pariwisata Indonesia.

Saran keempat, disampaikan kepada calon wisatawan yang akan datang ke Indonesia untuk selalu mengakses situs resmi pariwisata di Indonesia, dan mengunduh aplikasi telepon genggamnya, serta berpartisipasi dalam forum internet.

Saran kelima ditujukan kepada seluruh pelaku bisnis pariwisata, baik hotel maupun agen perjalanan, untuk selalu berpatokan pada informasi yang disampaikan pada situs resmi ini sehingga mencegah adanya informasi yang tidak valid di dunia internet.

Saran terakhir ditujukan kepada para peneliti dan mahasiswa, khususnya dalam bidang pariwisata, untuk melakukan penelitian selanjutnya mengenai sistem pariwisata elektronik di Indonesia dan Asia Tenggara, karena penelitian seperti ini jumlahnya masih cukup sedikit minim. Hal ini seiring beralihnya tren pariwisata tradisional menuju pariwisata modern berbasis teknologi digital.

\section{Ucapan Terima Kasih}

Penulis menyampaikan ucapan terima kasih kepada Gilbert Reveillon, Ph. D. dan Francois Xavier Decelle sebagai pembimbing penulis dalam proses penelitian dan penyelesaian tesis ini. Dalam proses pembuatan tesis ini, penulis juga ingin mengucapkan terima kasih kepada pihak kementerian pariwisata dan ekonomi kreatif Republik Indonesia, dalam hal ini Direktorat Pencitraan dan Promosi Digital, khususnya jajaran staf yang telah membantu penulis baik sebagai informan sekaligus atas masukan yang diberikan. Penulis juga ingin mengucapkan terima kasih kepada seluruh responden dan informan lainnya yang berperan dalam penyelesaian penelitian ini.

Lebih lanjut lagi, ucapan terima kasih juga penulis dedikasikan kepada Pemerintah Indonesia dan Prancis dalam hal ini Kementerian Pendidikan masing-masing yang telah merancang program Double Degree ini. Tidak lupa penulis juga ingin mengucapkan terima kasih kepada para dosen dan pegawai di lingkungan Program Magister Kajian Pariwisata, Program Pascasarjana, Universitas Udayana. Terakhir, tentu saja penulis ingin memberikan apresiasi dan penghargaan kepada orang tua, keluarga, dan sahabat, serta seluruh pihak yang telah memotivasi dalam penyelesaian tesis ini. 


\section{Daftar Pustaka}

Blond, Marie-Valentine, Olivier Marcellin, and Melina Zerbib. 2009. Lisibilité des Sites Web : Des Choix Typographiques au Design d'Information. Paris : Eyrolles.

Boerhanoeddin, Zuraida, 2005. E-Commerce In Indonesia. Indonesian Satellite Corp.

Buhalis, Dimitrios. 2003. eTourism Information Technology for Strategic Tourism Management. Harlow: Pearson Education Ltd.

Business Monitor International. 2014. Indonesia Information Technology Report. An online report published by Business Monitor on $9^{\text {th }}$ May 2014.

Business Insider. 2014. What's Happened During 60 Seconds. An Analysis from Business Insider Magazine on $7^{\text {th }}$ August 2014.

Cousin, Capucine avec Anaïs Richardin. 2014. Le Marketing Bientôt dans La $3^{\text {ème }}$ Dimension. Stratégies No 176227 Mars 2014 (16-18).

Crowder, David A. 2013. Créer Un Site Web Pour Les Nuls. Paris: First-Grund

Henderson, Prantner. 2005. On Tour Semantic Web Research Assistant : Seminar on Semantic Web Technologies. Austria. Presented in Seminar of Semantic Web Technologies Vienna 2005.

Karupiah, Premalatha and Jayaeswari Sangaralingam. 2008. Online Tourism Information : A Content Analysis of Southeast Asian Official Tourism Websites. Journal RARC International Conference 2008 Knowledge Infrastructure Management for Tourism.

Kaufman, Henri. 2014. Data des Objects Connectés et de L’internet Everywhere et : Quelles Applications Marketing Les Marques. Presented in E-Marketing Seminar 10th April 2014.

Kotler, Bowen, and Makens. 2006. Marketing for Hospitality and Tourism $4^{\text {th }}$ Edition. Pearson Education Inc.

Lee, Ilho. 2005. Wireless Access Protocol (WAP Architecture). WAP Forum.

$\mathrm{Li}, \mathrm{Xu}$ and Youcheng Wang. 2010. Is Your Official State Tourism Website Effective? A Functional Perspective. ICRT Model of American Destination Marketing Organization's 2010.

Masruroh. 2012. Indonesia MICE Promotion. Report of Ministry of Tourism Republic of Indonesia 2012.

Ministry of Tourism and Creative Economy Republic of Indonesia. 2012. Indonesia's Tourism Report 2012.

Reveillon, Gilbert. 2007. Web 2.o Le Nano-Marketing pour se Différencier. CCE International No 530 Février/Mars 2007.

Scowsill, David. 2014. WTTC : Indonesia Highest Growth in Tourism Industry. In online newspaper http://www.eturbonews.com/43805/wttc-indonesiahighest-growth-tourism-industry 19th March 2014.

UNCTAD. 2005. Information Economy : www.unctad.org/e-comerce http:// etourism.unctad.org/ 
UNCTAD, 2005. E-Tourism in Developing Countries, More Links and Fewer Leaks. Issues Brief Number 8.

World Economic Forum. 2012. The ASEAN Travel and Tourism Competitiveness Report 2012 : Fostering Prosperity and Regional Integration through Travel and Tourism. Geneva : Global Competitiveness Report World Economic Forum, directed by Professor Klaus Schwab.

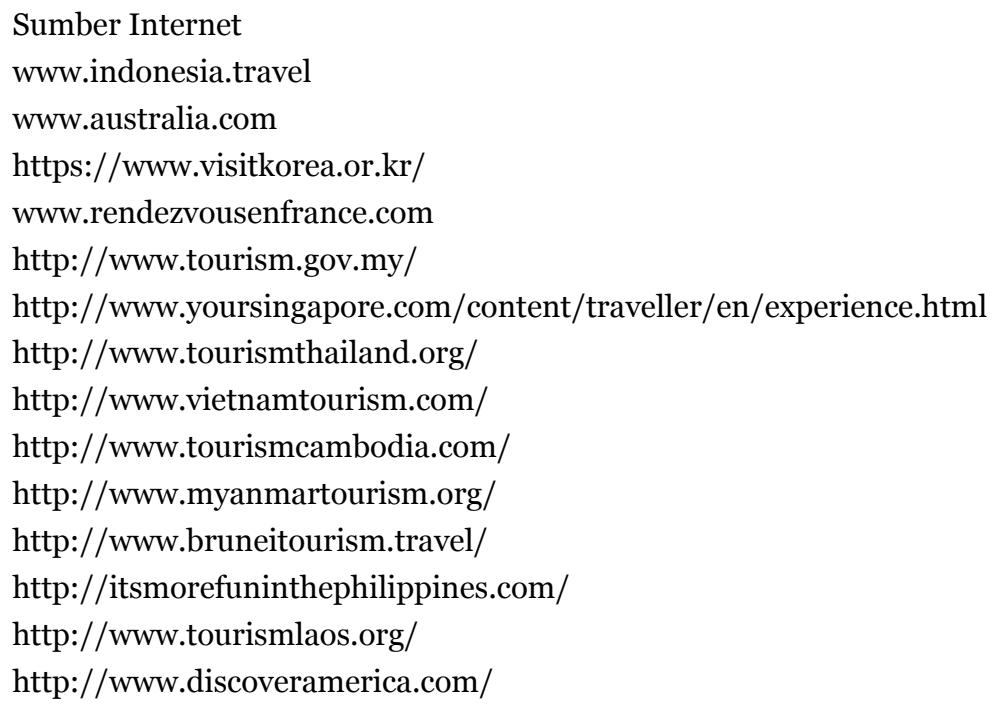

\section{Profil Penulis}

Made Handijaya Dewantara, S.ST.Par. adalah alumnus Magister Kajian Pariwisata, Double Degree Indonesia Prancis (DDIP), dengan menempuh 1 tahun pendidikan Master di Universitas Udayana Denpasar kemudian melanjutkan 1 tahun berikutnya di Prancis yaitu Université Paris 1 Panthéon Sorbonne, program studi Gestion des Activités Touristiques et Hôtelleries. Sebelumnya, dia menyelesaikan program studi Diploma IV, Administrasi Perhotelan di Sekolah Tinggi Pariwisata Nusa Dua Bali. Dia pernah bekerja dalam bidang sales and marketing, khususnya mengenai electronic marketing di Four Seasons Hotel Jakarta dan Puri Collection Sanur, Bali. Dalam program studinya di Prancis, dia melakukan program magang di perusahaan KTS France di Paris, dengan konsentrasi electronic tourism for sales and marketing, yang sekaligus menjadi bidang konsentrasinya. 